\author{
Hubertus Bardt ${ }^{1}$ \\ Cologne Institute for Economic Research, Germany
}

\title{
Potential Consequences of the Energiewende for the Manufacturing Sector in Germany
}

\begin{abstract}
$^{2}$
The abandonment of nuclear power and new focus on renewable energy sources represents a fundamental change in the structure of Germany's electricity supply. In the wake of this change in energy policy (which is widely referred to as an energy turnaround), prices started to rise immediately and further increases are to be expected in the years ahead. For the manufacturing sector, this cost burden has been mitigated by exempting energy-intensive sectors from additional costs. However, this causes high levels of uncertainty for large electricity consumers as their current exceptional status may be called into question at some point in the future.

Moreover, the price and cost effects of the German energy policy are not only restricted to energy-intensive enterprises. The metal production, parts of the chemical industry and other industries closely linked to electricity consumers in a complex value chain face higher price and cost risks, as do large segments of the manufacturing sector, which work closely with energy-intensive companies. These dense networks are critical in the joint development of innovations, one of the German industry's main competitive advantages.

This strength of the German economy may turn into a risk if the future of electricity-intensive industries is hampered by rising national energy prices. A potential relocation of energy-intensive companies to other countries would also weaken the competitiveness of other areas of German industry. Such risks need to be compared with new market opportunities provided by the energy turnaround. The industry seeks those opportunities especially in renewable energies and techniques for improving energy efficiency.
\end{abstract}




\section{Background: The Energiewende in Germany}

The German Energiewende is without international precedent. There is no blueprint to follow, no experience to draw conclusions from. The transition, phasing-out of nuclear energy and building an energy system based on renewable energies, is a challenge for energy producers and large consumers that can hardly be underestimated. The technical challenge is huge, but the need to organize a secure, affordable energy supply for a country with a large manufacturing sector adds additional complexity. Researchers and international institutions analyze various aspects of the Energiewende, including economic effects, technological options, security of supply and political processes. The International Energy Agency proposes to focus e.g. on cost reduction, further improvements of market regulation, and investments in distribution [IEA, 2013, p. 16.].

FIGURE 1. Renewable Energies in Germany Shares of electricity consumption, 2020-2050 government targets of 2010/2011

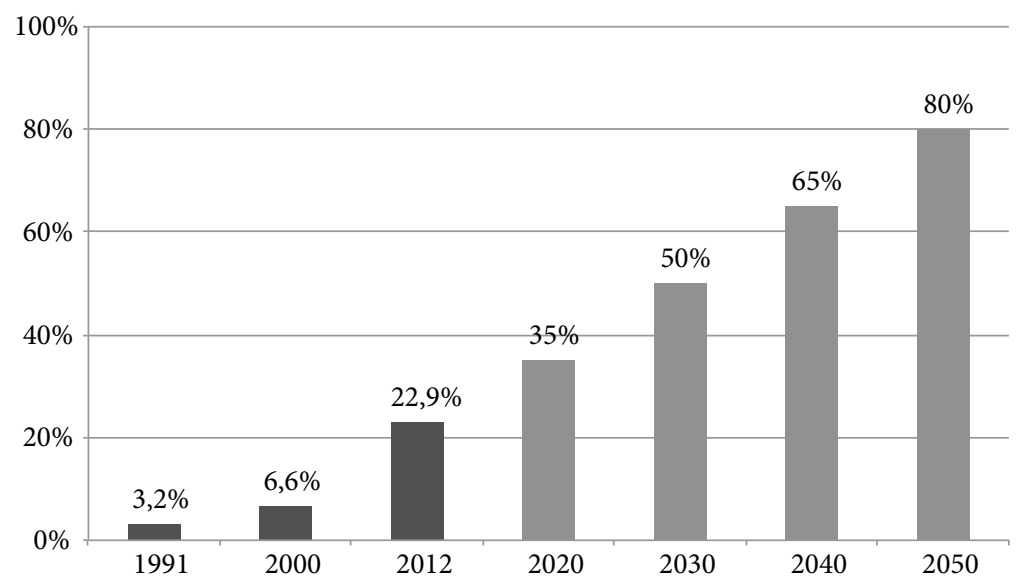

Source: ArbeitsgemeinschaftEnergiebilanzen; EEG.

The energy concept of 2010 and the accelerated phase-out of nuclear energy in 2011 mark the building of a consensus about transforming the energy system until 2050 [Bundesregierung, 2010; Bundesregierung, 2011]. While the Energiewende is supposed to reduce energy sector emissions, other dimensions of the energy trilemma need to be considered [Bardt, 2010, p. 4.; IW Köln, 2010, p. 2.]. While the political priority was to reduce environmental effects, security of supply and affordability remain important for economic development in an industrialized country like Germany. So far, security 
of supply has remained high, but prices have risen significantly due to the promotion of renewable energies and other instruments.

The core of the energy transition is the promotion of renewable energies that should dominate the electricity supply in the middle of the century. According to targets defined by the federal government, solar and wind power, biomass and other sources of renewable electricity should increase to meet 80 percent of total demand (Fig. 1). Since 1991, the share of power from these sources promoted by subsidies has increased from 3.2 percent to 22.9 percent in 2012 . After increasing by 20 percentage points in two decades, the remaining forty years until 2050 should bring an increase of an additional 60 percentage points.

The economic effects of the Energiewende are fundamental. The increase of retail prices due to rising levies on electricity consumption can endanger the competitiveness of certain companies and industries. Higher electricity costs can have a negative effect on domestic investments. These relations will be discussed in this paper.

\section{Overview and Methods}

The energy transition in Germany aims at an energy supply that produces most electricity with renewable energies by mid-century. What seems to be a smooth transition for the electricity sector can have a fundamental influence on the manufacturing sector. All large consumers of electric energy face additional risks regarding security of supply and additional costs. A stable supply of electricity is essential for production processes, public infrastructure, and private households [Petermann et al., 2010, p. 29]. While a decrease in security of supply is a rather subtle process, threats from additional costs caused by higher energy prices are more obvious. Political debates about an additional burden for energy-intensive industries to finance feed-in tariffs for renewable energies add strategic risks, which make decisions to invest in Germany more difficult. This is most critical for energy-intensive industries. However, industries with a lower share of electricity costs may face a negative impact on their competitiveness if value chains are disrupted because of energy politics. On the other side, additional opportunities can also arise from the energy transition, which have to be weighed against the threats caused by increasing electricity prices.

This paper presents opportunities and threats arising from the Energiewende for the manufacturing sector, focusing on the effects of rising electricity costs on private investment. The analysis of the indirect risks and opportunities arising from the energy transition for non-energy-intensive industries is based on a broad survey, which was conducted in 2012. Depending on the questions and filters applied, 250 to 1,500 manufacturing sector executives in Germany have been surveyed [Bardt, Kempermann, 2013, p. 20; Bardt, Kempermann, 2014, p. 4.].Most of the results allow differentiating between 
two types of companies, type-D and type- 0 . There are three success criteria that describe type-D companies [Baal, Lichtblau, 2012, p. 233.]: they are working on international markets; they invest above average in research and development; and they are more innovative than other companies. About 60 percent of the companies in the manufacturing sector can be classified as type-D. In contrast, type- 0 companies do not meet more than one of the criteria. These companies are significantly less successful regarding turnover, employment, profits and prospects.

Additionally, some of the results will be differentiated by the following industries: chemical, machinery, metals and metal products, and electronics and vehicles. All results will be extrapolated based on employment data. This allows a quantifying of the results according to the respective significance for the manufacturing sector.

\section{Direct Cost Effects}

Today, many companies realize the first effects of the Energiewende. The German energy transition assumes the fading out of nuclear energy until 2022. Its main focus, however, is to increase the share of electricity production from renewable energies to more than 80 percent by 2050 .

One of the main problems for the manufacturing sector here involves increasing energy prices. While market-based net electricity prices have remained fairly constant over the last years, there has been a significant increase of taxes and other government-related charges. More than 80 percent of companies face rising energy prices due to increasing levies on electricity. This share will probably grow over the next years (Fig. 2). Expectations regarding future developments have not been explained in the survey; but they will probably influence investment decisions, whether they are justified or not.

Almost one in four companies has identified better market opportunities due to the energy transition. One company out of six believes in increasing turnover in the short term, e.g., because they produce energy-efficient technologies. Medium-term prospects are a little better. The share of companies that fear threats for existing markets is similar. In the short run, about 10 percent expect a decline in employment and turnover as price competitiveness may be endangered. In the medium run, these shares are higher: 24 percent of the companies fear lower employment figures, while 16 percent expect a decrease in turnover.

The largest policy impact is expected in the future stability of energy supply. Only 12 percent of the companies see a short-term decline of security as a consequence of the Energiewende. In the medium run, this share is about 20 percentage points higher: a third of companies assume constraints of electricity supply. Rising energy costs are among the main challenges for the manufacturing sector. This is especially true for energy-intensive 
companies. Costs that apply only in Germany and not in other countries can become a significant threat if energy is the main cost factor for a company.

\section{FIGURE 2. Expected consequences of the Energiewende „Does the Energiewende have direct consequences for your company?" (share of answers, by percent, of all companies surveyed)}

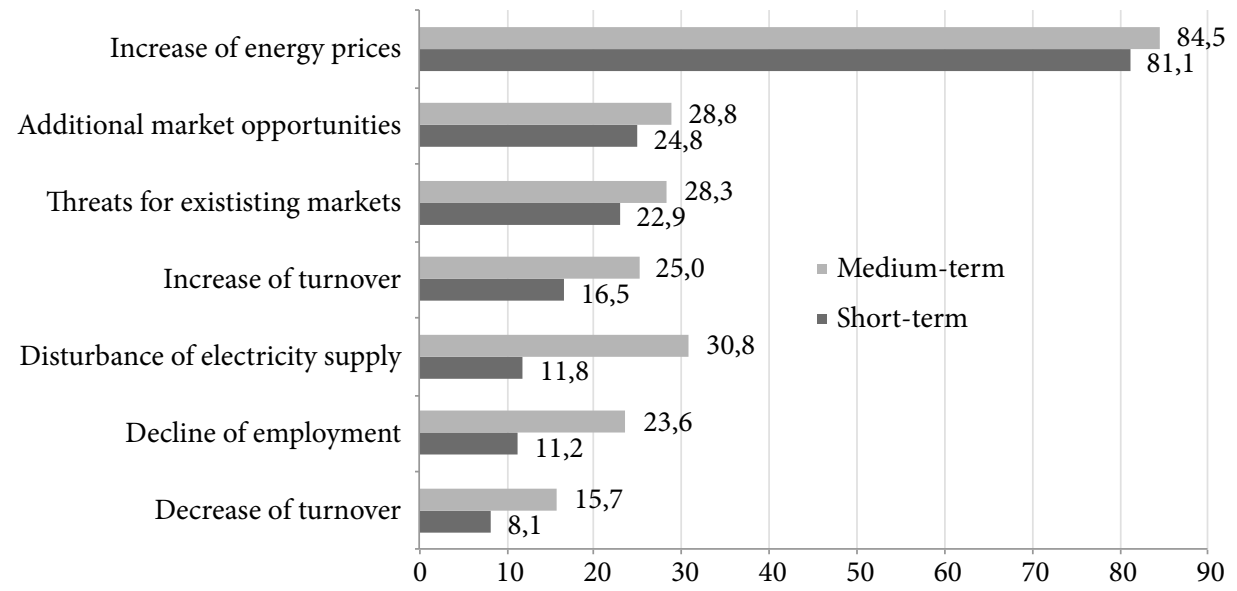

Expectations can influence investment decisions regardless of their justification.

S o u r c e: IW-Zukunftspanel 2012.

TABLE 1. Direct effects of the Energiewende (in percent)

\begin{tabular}{|l|c|c|c|c|c|c|c|}
\cline { 2 - 8 } \multicolumn{1}{c|}{} & $\begin{array}{c}\text { Manufacturing } \\
\text { sector }\end{array}$ & Type-0 & Type-D & $\begin{array}{c}\text { Chemical } \\
\text { industry }\end{array}$ & $\begin{array}{c}\text { Metals } \\
\text { and metal } \\
\text { products }\end{array}$ & Machinery & $\begin{array}{c}\text { Electronics } \\
\text { and } \\
\text { vehicles }\end{array}$ \\
\hline $\begin{array}{l}\text { Additional market } \\
\text { opportunities }\end{array}$ & 24.8 & 18.8 & 26.8 & 21.9 & 17.5 & 28.4 & 42.1 \\
\hline $\begin{array}{l}\text { Threats for existing } \\
\text { markets }\end{array}$ & 22.9 & 16.0 & 24.2 & 33.3 & 41.8 & 10.1 & 13.6 \\
\hline Additional turnover & 16.5 & 11.2 & 19.0 & 4.4 & 9.0 & 17.4 & 35.8 \\
\hline Loss of turnover & 8.1 & 8.4 & 7.2 & 6.0 & 8.6 & 4.7 & 16.7 \\
\hline Rising energy costs & 81.1 & 72.2 & 83.3 & 81.2 & 77.9 & 70.8 & 91.8 \\
\hline $\begin{array}{l}\text { Decreasing } \\
\text { employment }\end{array}$ & 11.2 & 9.0 & 13.0 & 15.5 & 17.7 & 4.1 & 12.5 \\
\hline $\begin{array}{l}\text { Reduced security of } \\
\text { supply }\end{array}$ & 11.8 & 6.0 & 14.3 & 18.5 & 18.9 & 3.4 & 11.8 \\
\hline
\end{tabular}

S o u r c e: IW-Zukunftspanel 2012. 
Table 1 shows more detailed results, indicating significant differences between selected industries and types of companies. While, for example, more than 40 percent of all electronics and automotive industry companies believe in additional market opportunities, over 40 percent of those in the metal industry expect threats for existing markets. Turnover developments show differences as well: about one out of three electronics or automotive companies has realized rising turnover due to the Energiewende. In contrast, this was only true for one out of eleven companies in the metal industry and one out of twenty in the chemical industry.

Companies that are innovative, do research, and work internationally gain more benefits from the energy transition than others. Almost 20 percent of these type-D companies managed to increase their turnover, as against 11 percent of type- 0 companies. Rising energy costs are more important for type- $D$ than for type- 0 companies. About 83 percent of the more successful businesses face higher costs. The share among type- 0 companies is about 11 percentage points lower.

To identify those industries that are most affected by rising electricity prices, absolute consumption of electricity and energy intensity should be considered. The chemicals and metal industry alone consume 19 and 18 percent of the electricity delivered by electricity suppliers to the manufacturing sector. Other industries, like automobile, construction, paper, food, glass and machinery production use only between 5.5 and 8.3 percent of the industrial demand of electricity. Furthermore, energy intensity is very high in the paper and chemical industry, along with the glass and ceramic, and metal industries.

The new energy policies, in conjunction with their impact on electricity prices, have become very important for German enterprises. According to a poll conducted by KfW, 61 percent of all German companies think that energy costs are an important factor when decisions about new investments are made [KfWBankengruppe / ZEW, 2012, p. 38.].

The development of net investment by energy-intensive industries reveals a difficult situation and a lack of confidence in high quality of electricity supply and, in particular, in competitive energy prices in Germany (Fig. 3). In non-energy-intensive industries, net investment has amounted to between -15 and +10 percent of gross investment over the last decade. In total, the sum of gross investments since 2000 almost equals depreciation, which results in a total net investment of 0 in the non-energy-intensive industries. While capital stock has been more or less stable in other industries, the situation of energy-intensive industries has been very difficult. In most years since 2000, net investment by the chemical, paper, glass and ceramic, and metal industry has been negative. In these industries, depreciation has been higher than gross investment. In 2005, for example, net investments were about 28 percent lower than depreciation. Only in 2008 was a positive net investment balance observed. Over the last decade, only 85 percent of all depreciation in energy-intensive industries has been replaced by investments. This is a slow process of disinvestment, which cannot be explained with high energy prices only. But the situation will probably become more critical with a rising national tax burden on energy. 
FIGURE 3. Disinvestment of energy-intensive industries (chemicals, metal, paper, glass and ceramic industries). Net investment as a percentage of gross investment

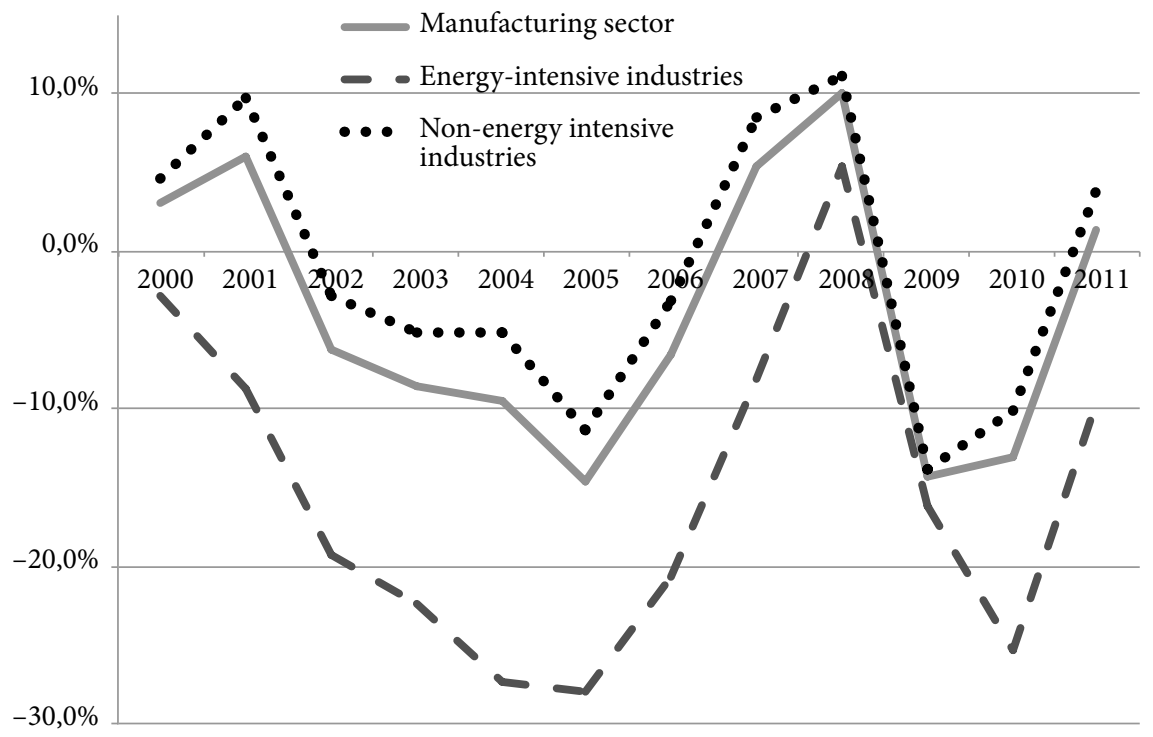

S o u r c e: Statistisches Bundesamt, 2013; own calculations.

As wholesale prices have recently fallen, large consumers of electricity, which typically pay below wholesale prices and avoid most taxes and levies, are shielded from higher costs. However, most of the special regulations and exemptions that protect these companies from rising levies are limited in time. Future price development is unclear and a major increase following the end of the exemptions is possible. Although the current price is competitive this unclear perspective endangers investment by these companies,.

\section{Indirect Effects on Value Chains and Innovation}

The Energiewende has not only direct (price) effects on energy-intensive industries. There will also be indirect consequences when current value chains or networks are affected. The German economy is characterized by a broad structure of different industries and intensive supply chain networks, which allow a high degree of specialization and division of labor. The specialization or concentration on core competences generates competitive advantages. At the same time, specialization in value chains leads to additional dependencies. If an important supplier drops out, the value chain cannot be sustained. Negative economic consequences for a number of companies in the affected value chain therefore become both possible and probable. 
TABLE 2. Influence of energy-intensive companies relocating abroad (in percent)

\begin{tabular}{|l|c|c|}
\cline { 2 - 3 } \multicolumn{1}{c|}{} & $\begin{array}{c}\text { Negative effects on success of own } \\
\text { business }\end{array}$ & $\begin{array}{c}\text { Negative effects on R\&D } \\
\text { networks }\end{array}$ \\
\hline Metals and metal products & 59.3 & 35.4 \\
\hline Chemical products & 38.6 & 15.3 \\
\hline Machinery & 29.0 & 10.1 \\
\hline Electronics and vehicles & 32.9 & 13.6 \\
\hline Manufacturing sector (total) & 35.7 & 12.9 \\
\hline
\end{tabular}

S o urce : IW-Zukunftspanel 2012; IW Consult, 2012.

More than 80 percent of the companies asked in the survey have energy-intensive suppliers. They have very close relations within value chains, but further network relations are intense as well: more than 40 percent of all companies in the manufacturing sector co-operate in networks with energy-intensive industries. About a third of the companies of the manufacturing sector see the risk that German suppliers could drop out of the supply chain. The share of companies that co-operate with energy-intensive industries and fear a negative influence on the stability of the value chains is above average. About 40 percent of these companies believe in risks for the supply chain. In contrast, only a quarter of the companies without any cooperation with energy-intensive industries believe so.

The Energiewende can become a real threat to the stability of existing value chains. Companies expect to be indirectly affected if energy-intensive companies lose competitiveness and relocate from Germany due to rising energy costs. Since close relations between energy-intensive and other companies are evident, insecurity cannot be limited to certain sectors. More than a third of all companies in the manufacturing sector expect negative consequences on their own business success if energy-intensive industries lose competitiveness in Germany and 13 percent believe that their domestic research and development networks are endangered as energy-intensive industries have specific core functions in these networks (Table 2).

The long run competitiveness innovation capacities of energy-intensive industries are important for other parts of the manufacturing sector as well (Table 3 ). The share of manufacturing sector companies that name the innovation potential of energy-intensive industries in Germany as an important factor for their own company is more than 70 percent. Innovative chemicals or metal producing companies contribute to the success of a large part of the German economy. The most successful companies (type-D) rely more than other businesses on energy-intensive industries as the innovation capacities of energy-intensive industries are important for three quarters of these companies. Moreover, about 45 percent of the companies in the manufacturing sector receive important innovation impulses from cooperating with energy-intensive companies.

With energy-intensive industries relocating from Germany, the structures of existing value chains would need to be rearranged. Furthermore, domestic research and development 
networks would be weakened since the innovation impulses of energy-intensive industries for the manufacturing sector in Germany would be reduced, weakening innovation potential and the competitiveness of the whole economy.

TABLE 3. Innovation capacities of energy-intensive industries (in percent)

\begin{tabular}{|l|c|c|c|}
\cline { 2 - 4 } \multicolumn{1}{c|}{} & Type-0 & Type-D & Manufacturing sector \\
\hline Innovation capacities of energy-intensive industries are important for the success of the own business. \\
\hline Very important & 6.6 & 25.4 & 23.6 \\
\hline Somewhat important & 42.6 & 47.7 & 46.7 \\
\hline Hardly important & 43.8 & 24.6 & 27.2 \\
\hline Not at all important & 7.0 & 2.3 & 2.5 \\
\hline Co-operation with energy-intensive industries leads to innovation impulses. \\
\hline Yes, regular impulses & 4.7 & 9.4 & 9.7 \\
\hline Yes, occasional impulses & 20.4 & 38.1 & 36.7 \\
\hline No impulses & 74.9 & 52.5 & 53.6 \\
\hline
\end{tabular}

S o u r c e: IW-Zukunftspanel 2012; IW Consult, 2012.

TABLE 4. Influence of the location of energy-intensive industries (in percent)

\begin{tabular}{|c|c|c|c|}
\hline & Type-0 & Type-D & Manufacturing sector \\
\hline $\begin{array}{l}\text { We would source energy-intensive products abroad, but } \\
\text { would not pursue common research and development. }\end{array}$ & 11.8 & 12.9 & 12.5 \\
\hline $\begin{array}{l}\text { We would source energy-intensive products abroad and } \\
\text { would conduct common research and development. }\end{array}$ & 1.7 & 16.9 & 15.3 \\
\hline $\begin{array}{l}\text { It depends on the country the supplier would relocate } \\
\text { to (distance, regulation etc.). }\end{array}$ & 27.3 & 28.6 & 29.3 \\
\hline It does not matter in which country the supplier is located. & 59.2 & 41.6 & 42.8 \\
\hline
\end{tabular}

S o u r c e: IW-Zukunftspanel 2012; IW Consult, 2012.

The results discussed so far show that energy-intensive industries play a vital role for the value chains and innovation activities of the German economy. In this context, where these suppliers are located is relevant. Less than 43 percent of the manufacturing sector think that it does not matter in which country the energy-intensive companies they cooperate with are located. Almost a third of the companies state that future cooperation depends on which country energy-intensive suppliers would relocate to. One in eight manufacturing sector companies would import products, but would not rebuild common research and development. A slightly higher share would do both, no matter where these parts of the value chain are based (Table 4). 
Many companies of the manufacturing sector in Germany are sceptical about common research and development with energy-intensive suppliers from abroad. Table 5 shows the obstacles impeding better international co-operation. Three of these obstacles are relevant for more than half of the companies of the manufacturing sector: the complexity of contracts; large geographical distances; and potentially higher costs. Almost 30 percent of the German manufacturing sector believe that in many countries technological competences of energy-intensive companies do not meet necessary standards. This is especially relevant for the machinery and metal industry. In addition, almost 40 percent of the companies see lack of trust as the main obstacle for further cooperation in research and development.

TABLE 5. Obstacles for common research and development in energy-intensive industries abroad (in percent)

\begin{tabular}{|l|c|c|c|}
\cline { 2 - 4 } \multicolumn{1}{c|}{} & Type-0 & Type-D & Manufacturing sector \\
\hline Complexity of contracts & 61.2 & 58.2 & 58.9 \\
\hline Large geographical distances & 51.1 & 49.8 & 51.7 \\
\hline High costs & 44.2 & 48.2 & 50.0 \\
\hline Language barriers & 37.5 & 36.5 & 39.2 \\
\hline Lack of trust & 30.3 & 38.1 & 38.1 \\
\hline Cultural obstacles & 21.6 & 32.4 & 32.3 \\
\hline Deficient technological competences & 20.6 & 30.0 & 28.5 \\
\hline
\end{tabular}

S o u r c e : IW-Zukunftspanel 2012; IW Consult, 2012.

Deficient competences in technology are foremost a concern of type-D companies. As they are highly human capital-intensive, technological know-how is much more important for them than it is for type-0 companies. Furthermore, type-D companies focus more on lack of trust and cultural obstacles, perhaps because of their more extensive experience with international cooperation, especially outside of Europe.

These obstacles are relevant for international cooperation with energy-intensive industries and also for all kinds of cooperation in research and development with foreign partners. Distortions of existing value chains and cooperation due to the relocation of certain industries would cause a long-lasting loss for the economy as a whole, as many German companies would not be able to establish adequate networks with international partners.

The survey results reveal that rising domestic energy prices would not only endanger energy-intensive industries, but also negatively impact other parts of the manufacturing sector. The potential relocation of energy-intensive companies would destroy supply chains and innovation networks, weakening the innovative potential of important industries. These networks are often based on cooperation between partners from different industries, many of which are part of the domestic energy-intensive sector. In many instances, it is 
impossible to replace these with new international innovation partners, at least in the short run. This is especially threatening for the more successful innovation-intensive type-D companies, which are most important for economic development and prosperity in Germany. Securing existing value chains and innovation networks should no longer be underestimated.

\section{FIGURE 4. Business opportunities caused by the Energiewende (in percent)}

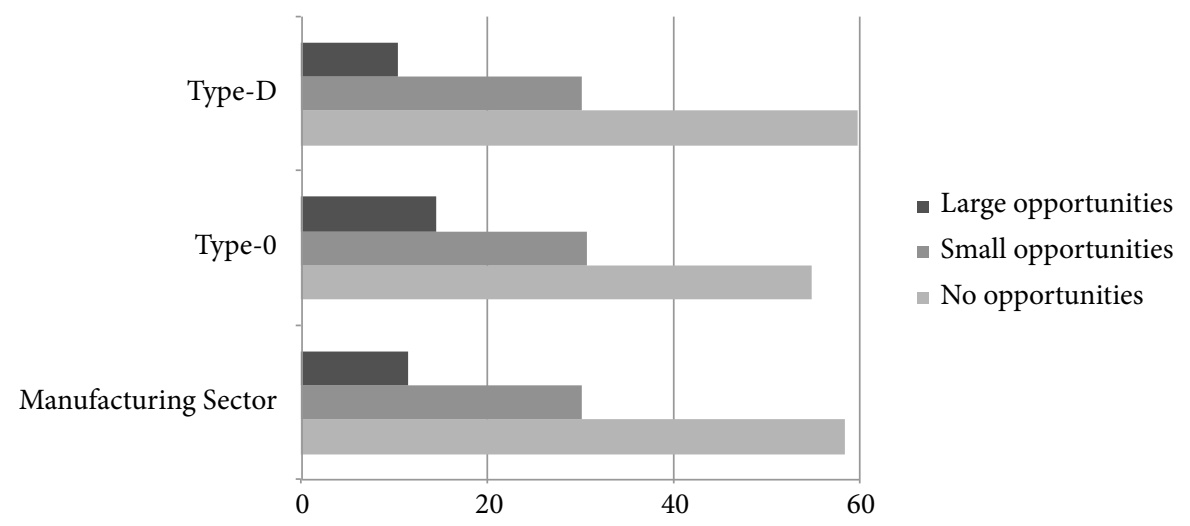

S o u r ce : IW-Zukunftspanel 2012.

\section{Opportunities for the Manufacturing Sector in Germany}

The Energiewende creates not only risks to the manufacturing sector; new business opportunities are linked with the energy transition process as well, not only in Germany but also globally [Kaminsky, 2010]. More than 11 percent of manufacturing companies believe in major opportunities for their businesses (Fig. 4). About a third of the companies expect minor opportunities. The majority of about 60 percent of the manufacturing sector, however, does not see new prospects in conjunction with the Energiewende. Only 10 percent of the type-D companies expect substantial opportunities, while almost 15 percent of the type- 0 companies are optimistic. This demonstrates that those companies, which are especially competitive and successful in today's markets and which are working in existing international value chains are most sceptical about the potential effects.

Table 6 lists the main business areas in which companies see the most opportunities related to the Energiewende. Renewable energies and energy efficiency are the most important options here, as 85 percent of the companies in the manufacturing sector that see opportunities focus on these areas. Another 4 percent expect growing business 
in energy-specific services. With more than 16 percent, this share is much higher in the group of business-related services and construction. Similarly, energy-related construction works are only relevant for 3 percent of the manufacturing sector, as against almost 20 percent of the other companies. Comparing different company types, it can be seen that the more innovative, international and successful companies (type-D) concentrate on energy efficiency, while the less successful type- 0 companies - which expect more opportunities from the Energiewende - focus on renewable energies.

TABLE 6. Fields of business with opportunities arising from the Energiewende (share of all companies that see opportunities, in percent)

\begin{tabular}{|c|c|c|c|}
\hline & \\
\hline & Type-0 & Type-D & Total sector \\
\hline \multicolumn{4}{|l|}{ Manufacturing sector } \\
\hline Renewable energies & 65.6 & 30.9 & 39.3 \\
\hline Energy efficiency & 17.5 & 54.7 & 45.7 \\
\hline Energy specific consultancy (e.g. „Green IT“) & 10.7 & 1.4 & 3.7 \\
\hline Building restoration (e.g. insulation) & 1.9 & 3.6 & 3.2 \\
\hline Other & 4.3 & 9.4 & 8.2 \\
\hline \multicolumn{4}{|l|}{ Business related services, construction } \\
\hline Renewable energies & 45.6 & 25.0 & 36.9 \\
\hline Energy efficiency & 9.0 & 17.6 & 12.6 \\
\hline Energy specific consultancy (e.g. „Green IT“) & 8.7 & 27.0 & 16.4 \\
\hline Building restoration (e.g. insulation) & 22.3 & 15.8 & 19.6 \\
\hline Other & 14.4 & 14.6 & 14.5 \\
\hline
\end{tabular}

S o u r c e: IW-Zukunftspanel 2012.

\section{Conclusions}

The transition of German energy brings risks and opportunities. Among companies in Germany there is much uncertainty about the consequences for the own businesses, with 80 percent manufacturing sector companies unsure if opportunities or risks are dominant. Only 1.2 percent believe that the Energiewende strengthens Germany as a business location, while 18.8 percent expect it to become weaker.

The Energiewende is most relevant for the energy sector and energy-intensive industries, which face higher prices or other risks of cost increases, and fear a loss of competitiveness on international markets. Notwithstanding, other companies of the manufacturing sector must be taken into consideration, too, as their innovation capacities partly result from 
close cooperation with energy-intensive suppliers. However, new market opportunities will arise as the energy transition is a game changer for important parts of the economy and cannot be seen as a technological challenge only. Especially innovative, export oriented and successful companies are closely linked to energy-intensive industries. Cooperative innovation is a competitive advantage, which would be at risk if energy prices were to endanger energy-intensive industries. These forms of cooperation could hardly be replaced by new international value chains in the short term. Cooperative innovation between different industries is one of the strengths of the manufacturing sector in Germany today. If innovation impulses from energy-intensive industries are reduced in the future, the position of other industries on world markets will become weaker. However, opportunities arising from the energy transition must not be forgotten. In this context, renewable energies and energy efficiency are the most important fields for the manufacturing sector. The less successful, international and innovative the companies are, the more opportunities in renewable energies arise. More global and innovative companies, on the other hand, focus on energy efficiency.

\section{Notes}

1 Dr. Hubertus Bardt, Managing Director, Head of Research, Cologne Institute for Economic Research, Germany; e-mail address: bardt@iwkoeln.de

2 This paper is based on a presentation at the Warsaw School of Economics in November 2014.

\section{References}

Baal, S. van, Lichtblau, K. (2012), Erfolgsfaktoren von Industrieunternehmen, in: Institut der deutschen Wirtschaft Köln, (eds.), Wirtschaftswachstum?! - Warum wir wachsen sollten und warum wir wachsen können, IW Studien - Schriften zur Wirtschaftspolitik aus dem Institut der deutschen Wirtschaft Köln, IW Medien Köln, pp. 243-256. Bardt, H. (2010), Energieversorgung in Deutschland - wirtschaftlich, sicher und umweltverträglich, IW Positionen - Beiträge zur Ordnungspolitikaus dem Institut der deutschen Wirtschaft Köln, IW Medien Köln, No. 45, Köln. Bardt, H., Kempermann, H. (2013), Folgen der Energiewende für die Industrie, IW Positionen - Beiträge zur Ordnungspolitik aus dem Institut der deutschen Wirtschaft Köln,IW Medien Köln, No. 58, Köln.

Bardt, H., Kempermann, H. (2014), The German Energiewende: is the manufacturing sector at risk?, Journal of Energy Markets, Vol. 7, No. 4, pp. 3-15.

Bundesregierung (2010), Energiekonzept für eine umweltschonende, zuverlässige und bezahlbare Energieversorgung, Berlin. 
Bundesregierung (2011), Der Weg zur Energie der Zukunft - sicher, bezahlbar und umweltfreundlich, Eckpunktepapier der Bundesregierung zur Energiewende, Berlin.

IEA (2013), Energy Policies of IEA Countries, 2013 Review, Germany, Paris.

IWConsult-Institut der deutschen Wirtschaft KölnConsult GmbH (2012), Netzwerke und Wertschöpfungsketten, Köln.

IW Köln - Institut der deutschen Wirtschaft Köln (2010), Energie für das Industrieland Deutschland, Köln.

Kaminsky, W. (2010), Energy Markets; in: L. Tvede, Supertrends: Winning Investment Strategies for the Coming Decades, Wiley.

KfW Bankengruppe, ZEW - Zentrum für Europäische Wirtschaftsforschung (2012), $\mathrm{CO}_{2}$ Barometer 2012, Frankfurt am Main/Mannheim.

Petermann, T., Bradke, H., Lüllmann, A., Poetzsch, M., Riehm, U. (2010), Gefährdung und Verletzbarkeit moderner Gesellschaften am Beispiel eines großräumigen Ausfalls der Stromversorgung, TAB Arbeitsbericht, No. 141. Statistisches Bundesamt (2013), Volkswirtschaftliche Gesamtrechnungen, Beiheft Investitionen, Wiesbaden. 